http://jmscr.igmpublication.org/home/ ISSN (e)-2347-176x ISSN (p) 2455-0450 crossref DOI: https://dx.doi.org/10.18535/jmscr/v7i9.51

\author{
(D) Journal Of Medical Science And Clinical Research \\ IGM Publication \\ An official Publication of IGM Publication
}

\title{
Estimation of Serum Electrolytes in Hyperthyroid Patients
}

\author{
Authors \\ Meenakshi Sharma ${ }^{1 *}$, Navneet Kour ${ }^{2}$ \\ ${ }^{1}$ Deptt. of Physiology, GMC, Kathua, Jammu and Kashmir \\ ${ }^{2}$ Deptt. of Physiology, GMC, Jammu, Jammu and Kashmir \\ *Corresponding Author \\ Dr Meenakshi Sharma
}

\begin{abstract}
Introduction: Various metabolic pathways clearly indicate how importantly thyroid and kidney are interrelated; any alteration of thyroid gland leads to change of thyroid hormone levels and modifies the renal function and any disorder in renal function can retard the normal pathway of thyroid hormone. So, the present study is planned to estimate the level of serum electrolytes in hyperthyroid patients.

Material and Methods: The study was undertaken in subjects of age group 20-65 years. Subjects were taken from outpatient department of medicine in Government Medical College, Jammu. Detailed explanation of the purpose and methodology of the tests was given to all subjects and all eligible subjects were requested to participate in the study. Subjects were divided into two groups.

Group A Euthyroid and Group B Hyperthyroid.

Conclusion: The present study shows that there is no significant difference in mean serum sodium and serum potassium between euthyroid and hyperthyroid subjects as this study was planned to show abnormalities of renal function in thyroid dysfunction.

Keywords: Serum electrolytes, hyperthyroidism.
\end{abstract}

\section{Introduction}

Water and electrolyte balance of various tissues of human body is partly regulated by $\mathrm{T} 4$ and $\mathrm{T} 3$ and the metabolism of thyroid hormones are accentuated by renal function and kidney is considered to be one of the vital tissues for thyroid hormones as well. Various metabolic pathways clearly indicate how importantly thyroid and kidney are interrelated; any alteration of thyroid gland leads to change of thyroid hormone levels and modifies the renal function and any disorder in renal function can retard the normal pathway of thyroid hormone. In either case, human metabolism is adversely affected and it will be accompanied by serious adverse effects resulting into various metabolic disorders ${ }^{[1,2,3,4]}$. Thyroid disorders adversely influence the kidney structure and function. ${ }^{[5,6,7,8]}$. It is believed that kidney deviation from its normal function, eventually affect thyroid gland and lead to thyroid malfunction ${ }^{[9]}$. So, the present study is planned to estimate the level of serum electrolytes in hyperthyroid patients.

\section{Material and Methods}

The present study was conducted in the Department of Physiology in collaboration with the Department of Medicine and Department of 
Biochemistry, Government Medical College, Jammu.

\section{Selection Procedure}

The study was undertaken in subjects of age group 20-65 years. Subjects were taken from outpatient department of medicine in Government Medical College, Jammu. Detailed explanation of the purpose and methodology of the tests was given to all subjects and all eligible subjects were requested to participate in the study. Subjects were divided into two groups.

Group A Euthyroid and Group B Hyperthyroid

\section{Eligibility Criteria}

Inclusion Criteria: Fresh cases of hyperthyroidism were detected by their clinical presentation and biochemical parameters. Patients of both sexes and 20 years of age were included.

Exclusion Criteria: Pre-existing diseases like diabetes mellitus, renal disorders, liver disorders or any other chronic inflammatory medical condition were excluded from the study. Weight and height were recorded as per standards recommended by WHO.

\section{Biochemical measurements}

Thyroid function tests (T3, T4 and TSH) were performed by chemilumniescent microparticle immunoassay for the quantitative determination of thyroid hormones in human serum and plasma $^{[10,11]}$. Renal function tests (Sr. urea, creatinine, uricacid, sodium and potassium) were estimated on fully automated analyser (Siemens Dimensionsxp and Plus). Handling and storage of blood samples were done as per criteria furnished by National Committee for Clinical laboratoryStandard (NCCLS).

\section{Statistical Analysis}

Data was subjected to one way analyses of variance (ANOVA). In all cases, means are used as units of analyses are represented as mean +SD. Individual values for each subject were taken as replicate and for each parameter 40 replicates were used in total. A p-value of less than 0.05 was considered statistically significant.

\section{Results}

Comparison of mean serum sodium of group A and group B subjects

\begin{tabular}{|l|c|c|c|c|}
\hline $\begin{array}{l}\text { Classification of } \\
\text { subjects }\end{array}$ & $\begin{array}{c}\text { Seum sodium } \\
(\mathrm{meqL})\end{array}$ & $\begin{array}{c}\text { Statistical inference } \\
\text { F-value }\end{array}$ & $\begin{array}{c}\text { Statistical inference } \\
\text { p-value }\end{array}$ & $\begin{array}{c}\text { Significant } \\
\text { difference }\end{array}$ \\
\hline Euthyroid & $141.03 \pm 2.02$ & $\mathrm{~F}=2.0447$ & $\mathrm{P}=0.1567$ & $\begin{array}{c}\text { Not significant as } \\
\mathrm{p}>0.05\end{array}$ \\
\hline Hyperthyroid & $140.38 \pm 2.05$ & & & \\
\hline
\end{tabular}

Comparison of serum potassium of group A and group B Subjects

\begin{tabular}{|l|c|c|c|c|}
\hline $\begin{array}{l}\text { Classification } \\
\text { of subjects }\end{array}$ & $\begin{array}{c}\text { Serum potassium } \\
(\mathrm{meq} \mid \mathrm{l})\end{array}$ & $\begin{array}{c}\text { Statistical inference } \\
\text { F-value }\end{array}$ & $\begin{array}{c}\text { Statistical inference } \\
\mathrm{p} \text {-value }\end{array}$ & Significant difference \\
\hline Euthyroid & $3.98 \pm 0.23$ & $\mathrm{~F}=0.0095$ & $\mathrm{P}=0.924$ & Not significant as $\mathrm{p}>0.05$ \\
\hline Hyperthyroid & $3.98 \pm 0.22$ & & & \\
\hline
\end{tabular}

Table shows there is no significant difference in mean serum potassium between euthyroid and hyperthyroid subjects.

\section{Discussion}

Thyroid hormones influence renal development, kidney structure, renal hemodynamics, glomerular filtration rate (GFR), function of many transport systems along the nephron and sodium and water hemostasis $^{[12]}$. The physiologic effects of hyperthyroidism may create increased hepatic oxygen consumption without an equal increase in blood flow, causing focal hypoxaemia and hepatic dysfunction ${ }^{[13]}$.It has also been hypothesised that these abnormalities are in part related to congestive heart failure and venous congestion caused by hyperthyroidism, although features of 
congestive hepatopathy were not evident in our patients liver biopsy ${ }^{[14]}$.

\section{Conclusion}

The present study shows that there is no significant difference in mean serum sodium and serum potassium between euthyroid and hyperthyroid subjects as this study was planned to show abnormalities of renal function in thyroid dysfunction.

\section{Bibliography}

1. Katz AI, Emmanouel DS and Lindheimer MD. Thyroid hormone and the kidney.Nephron 1975; 15: 223-249.

2. Capasso G, DeTommaso G, Pica A, Anast asio P, Capasso J, Kinne R and De Santo NG.Effects of thyroid hormones on heart and kidney functions. Mineral and Electrolyte Metabolism 1999; 25: 56-60.

3. Henry JB. Evaluation of liver function. Clinical Diagnosis and Management by Lab Methods, $12^{\text {th }}$ edition 2003; 275-76.

4. Kaptein EM. Thyroid function in renal failure. Contributions to Nephrology 1986; 50: 64-72.

5. Braunlich H. Thyroid hormones influencing renal electrolyte excretion in saline loaded rats of different ages. Physiologia Bohemoslovaca 1984; 33: 303-308.

6. Kaptein EM, Feinstein EI and Massry SG. Thyroid hormone metabolism in renal diseases Contributions to Nephrology 1982; 33: 122-135.

7. Brohee D, Delespesse G, Debisschop MJ and Bonnyns M. Circulating immune complexes in various thyroid diseases. Clinical and Experimental Immunology 1979; 36: 379-383.

8. Vargas F, Moreno JM, RodríguezGómez I, Wangensteen R, Osuna A, Alvarez-Guerra M and García-Estañ J. Vascular and renal function in experimental thyroid disorders. European

Journal

of Endocrinology 2006; 154: 197-212.

9. Kaptein EM, Quion-Verde H, Chooljian CJ, Tang WW, Friedman PE, Rodriquez HJ and Massry SG. The thyroid in endstage renal disease. Medicine1988; 67: 187-197

10. Patel YC, Alford FP and Burger HG.The 24 hour plasma thyrotropinprofile. Clin Sci 1972; 43: 71-77.

11. Sterling K and Lazarus JH.The thyroid and its control. Annu Rev Physiol 1977; 39: 349-71.

12. Den Hollander JG, Wulkan RW, Mantel MJ and Berghout A. Correlation between severity of thyroid dysfunction and renal function. Clinical Endocrinology 2005; 62(4): 423- 7.

13. Venditti P and Di MeoS. Thyroid hormone induced oxidative stress. Cell Mol Life and treatment of non- Hodgkin's lymphoma of the thyroid $\mathrm{g}$ land. Ann Surg Oncol 2001; 8: 338-41.

14. Dooner HP, Prada J, Aliaga C and Hoyl C. The Liver in Thyrotoxicosis. Arch Intern Med 1967; 120(1): 25-32. 